\title{
Mid-life crises among the sandwich generation people
}

\author{
Vijayalakshmi S. \\ Assistant Professor of Perspective in Education, Loyola College of Education, Chennai, Tamilnadu \\ Corresponding author: Vijayalakshmi S.
}

Email - nithyavijayas@gmail.com

\begin{abstract}
Background: A midlife crisis is a transition of identity that can occur in individuals. It is a psychological and behavioral observation that occurs with individuals between the age group of 35-50 years. The major objectives of the study are to find the level of mid-life crises and on its dimensions among sandwich generation people. To find the significance difference between men - women sandwich generation people on mid-life crises and on its dimensions. Hypotheses were framed on basis of the objectives.

Methodology: Normative survey method was used in the present research. Data were collected using selfconstructed and validated tool. A sample of 262 sandwich generation people was considered as sample for the study and data were statistical analysis using SPSS.

Results: Results of the study reveals that the female sandwich generation people are at higher level than the male sandwich generation people in mid-life crises. In the dimensions of self-related crises, family related crises females are at higher level than the male. Whereas, no significance difference was found between male and female sandwich generation people in other mid-life crises dimension.

Conclusion: There is a need to cope with crises situation in life. The suggestion was given by researcher to cope with the crises and live mentally healthy.
\end{abstract}

Key words: Mid-life, Crises, Sandwich generation and normative survey method.

(Paper received $-24^{\text {th }}$ September 2017, Peer review completed $-10^{\text {th }}$ November 2017)

(Accepted $-12^{\text {th }}$ November 2017)

\section{INTRODUCTION}

A midlife crisis is a transition of identity and self-confidence that can occur in individuals. It is a psychological and behavioral observation that commonly occurs in individuals between the age group of 35-50. While some individuals may experience feelings of depression, remorse, and anxiety, others may experience feelings such as the desire to achieve youthfulness or make drastic changes to their current lifestyle [1]. Middle life, is a sensation of passing their youth and the nearness of their old age. Sometimes a crisis can be triggered by transitions of experience in these years such as extramarital affairs, andropause or menopause, the death of parents or other causes of grief, unemployment or underemployment, realizing that a job or carrier is hated but not knowing how else to earn an equivalent living, or children leaving home, crises on financial settlements etc [2].

Many middle aged adults experience major life events that can cause a period of psychological stress or depression, such as the death of a loved one or a carrier set back. But new research suggests that people all over the world are miserable in middle age. Some people suffer more than others, "it happens to men and women, to single and married people, to rich and poor, and to those with and without children" [3].

The term "midlife crisis" was originally coined by Jaques [4] on the basis of his study on the personal experiences of artists, concluded that midlife people encountered a period of crisis which was triggered by the realization of their own mortality and change in time frame from "time since birth" to "time left to 
live". The idea of midlife crisis or midlife transition was subsequently proposed in several models on adult development [5-7]. In these models, it is suggested that a midlife generation people would be increasingly aware of mortality and the time left, and in response to such awareness, they would evaluate their life, particularly with respect to one's family, work and existence. But new research suggests that people all over the world are miserable in middle age.

The aim of the current study was to find out the level of mid-life crises and its dimensions among the sandwich generation people and to find out the significance differences between the sandwich generation men and women in mid-life crises and in its dimensions.

\section{METHODOLOGY}

\section{Hypotheses of the study}

- There exist significant differences in the level of mid-life crises among the sandwich generation people.

- There exist significant differences in the level of dimensions of mid-life crises among the sandwich generation people.

- There exist significant differences between the sandwich generation men and women in mid-life crises.

- There exist significant differences between the sandwich generation men and women in dimensions of mid-life crises.

\section{Operational definitions}

Mid-life crises: crises that occurs for the people of age group of 30s- 50s. Crises like bringing up their children, caring aging parents, under-employment, financial plans and etc.

Sandwich generation: generation of people at the age of their thirties to fifties.

\section{Methodology}

Normative survey method was used in the present research. A sample of 262 sandwich generation people was considered as sample for the study. The study was conducted in various parts of Tamilnadu. Convenience sampling, a non-probability method of sampling technique was adopted to conduct the survey. In the sample of 262 sandwich generation people 140 were females and 122 were males.

The Mid-Life Crisis scale was used in this study to collect data. It is a self-constructed and validated tool. The mid-life crisis scale was constructed with 35 items among that 15, 12, and 8 numbers of items were allotted for the three dimensions like self-related crises, family related crises and other mid-life crises respectively. It is a three point 'Likert' type scale and responses are: agree, neutral and disagree.

The scoring of the items are 3, 2 and 1 . The score ranges from 105-35. The score ranges from 35-57 states as low level of mid-life crises, score range from 58-81 as average level of midlife crises and the score ranges from $82-105$ is termed as high level of mid-life crises.

\section{Validation of the tool}

The tool was validated by establishing reliability and validity. Reliability was established by using test retest method the $\mathrm{r}$ value for test re-test method is 0.74 which states it is reliable. Validity of the tool was established by content validity.

\section{Dimensions of the tool}

The dimensions of the mid-life crises are: self-related problems, Family-related problems and other mid-life problems.

Self-related problems: this includes crises related to worrying about age, lack of achievements, no time for self-achievements, evaluation of work life and inability to enjoy the leisure time.

Family-related problems: this includes issues related to evaluation of martial relationship, feelings about parent-children relationship, stress on taking care of old age parents or in-laws and financial issues. 
Other mid-life problems: this includes crises related to fear of aging, meaning of life, psychological wellbeing, health issues and existential confusion.

\section{RESULTS}

There exist significant differences in the level of mid-life crises among the sandwich generation people.

Table 1 - Levels of mid-life crises and its dimensions among sandwich generation

\begin{tabular}{|c|c|c|c|c|c|c|}
\hline $\begin{array}{c}\text { Mid-life crises } \\
\text { and its } \\
\text { Dimensions }\end{array}$ & $\begin{array}{c}\text { Low } \\
\text { mid-life } \\
\text { crises } \\
\mathbf{N}\end{array}$ & Percentage & $\begin{array}{c}\text { Average } \\
\text { mid-life } \\
\text { crises } \\
\mathbf{N}\end{array}$ & Percentage & $\begin{array}{c}\text { High } \\
\text { mid-life } \\
\text { crises } \\
\mathbf{N}\end{array}$ & Percentage \\
\hline Mid-life crises & 32 & 12.21 & 31 & 11.83 & 199 & 75.95 \\
\hline
\end{tabular}

The table indicates that $12.21 \%$ of sandwich generation people have low level of mid-life crises. $11.83 \%$ of sandwich generation people have average level of mid-life crises and $75.95 \%$ of sandwich generation people have high level of mid-life crises. This shows that the sandwich generation people are more prone to midlife crises.

There exist significant differences in the level of dimensions of mid-life crises among the sandwich generation people.

Table 2 - Levels of mid-life crises dimensions among sandwich generation

\begin{tabular}{|c|c|c|c|c|c|c|}
\hline $\begin{array}{c}\text { Dimensions } \\
\text { of Mid-life } \\
\text { crises }\end{array}$ & $\begin{array}{c}\text { Low mid- } \\
\text { life crises } \\
\mathbf{N}\end{array}$ & Percentage & $\begin{array}{c}\text { Average } \\
\text { mid-life } \\
\text { crises } \\
\mathbf{N}\end{array}$ & Percentage & $\begin{array}{c}\text { High mid- } \\
\text { life crises } \\
\mathbf{N}\end{array}$ & Percentage \\
\hline $\begin{array}{c}\text { Self-related } \\
\text { crises }\end{array}$ & 112 & 42.74 & 83 & 31.67 & 67 & 25.57 \\
\hline $\begin{array}{c}\text { Family } \\
\text { related crises }\end{array}$ & 88 & 33.58 & 62 & 23.66 & 112 & 42.77 \\
\hline $\begin{array}{c}\text { Other mid- } \\
\text { life crises }\end{array}$ & 111 & 42.36 & 105 & 40.07 & 46 & 17.55 \\
\hline
\end{tabular}

From the table 2 it is inferred that the high level of mid-life crises was found in the dimension of family related issues. Further, the low level of mid-life crises among sandwich generation people are found in selfrelated crises followed by other mid-life crises.

There exist significant differences between the sandwich generation men and women in mid-life crises.

Table 3 - Difference between men and women in mid-life crises among sandwich generation

\begin{tabular}{|l|l|l|l|l|l|}
\hline Gender & N & Mean & SD & t & p value \\
\hline Female & 140 & 96.09 & 8.25 & \multirow{2}{*}{$8.407^{* *}$} & \multirow{2}{*}{$0.001^{*}$} \\
\hline Male & 122 & 77.93 & 23.98 & & \\
\hline
\end{tabular}

From the table 3 it was found that the $t$ value of mid-life crises of sandwich generation is significant at 0.01 level of significance. Hence the hypothesis is accepted and it is inferred that there is significant difference in mid-life crises between men and women sandwich generation people. 
The mean value states that the female sandwich generation people are at higher level than the male sandwich generation people in their mid-life crises.

There exist significant differences between the sandwich generation men and women in the dimensions of mid-life crises.

Table 4 - Difference between men and women in dimensions of mid-life crises among sandwich generation

\begin{tabular}{|c|c|c|c|c|c|c|}
\hline $\begin{array}{l}\text { Dimensions of } \\
\text { Mid-life crises }\end{array}$ & Gender & $\mathbf{N}$ & Mean & SD & $\mathbf{t}$ & p value \\
\hline \multirow{2}{*}{$\begin{array}{l}\text { Self- related } \\
\text { crises }\end{array}$} & Female & 140 & 29.63 & 8.94 & \multirow{2}{*}{$2.96^{* *}$} & \multirow{2}{*}{$0.001^{*}$} \\
\hline & Male & 122 & 26.48 & 8.14 & & \\
\hline \multirow{2}{*}{$\begin{array}{c}\text { Family- related } \\
\text { crises }\end{array}$} & Female & 140 & 26.95 & 6.74 & \multirow{2}{*}{$6.59 * *$} & \multirow{2}{*}{$0.001^{*}$} \\
\hline & Male & 122 & 20.71 & 8.54 & & \\
\hline \multirow{2}{*}{$\begin{array}{l}\text { Other mid-life } \\
\text { crises }\end{array}$} & Female & 140 & 13.71 & 4.41 & \multirow{2}{*}{1.68} & \multirow{2}{*}{$0.09 \mathrm{NS}$} \\
\hline & Male & 122 & 14.61 & 4.29 & & \\
\hline
\end{tabular}

From the table 4 it was found that the $t$ value of self-related dimension of mid-life crises of sandwich generation is significant at 0.01 level of significance. Hence the hypothesis is accepted and it is inferred that there is significant difference in self-related dimension of mid-life crises between men and women sandwich generation people. Further, it is inferred that the female sandwich generation people are at higher level than the male sandwich generation people in their self-related crises dimension of mid-life crises. From table it was found that the $t$ value of family-related dimension of mid-life crises of sandwich generation is significant at 0.01 level of significance. Hence the hypothesis is accepted and it is inferred that there is significant difference in family-related dimension of mid-life crises between men and women sandwich generation people. Further, it is inferred that the female are at higher level than the male sandwich generation people in their family-related crises dimension of mid-life crises. From table it also found that the $t$ value of other mid-life crises dimension of sandwich generation is not significant at 0.05 level of significance. Hence the hypothesis is rejected and it is inferred that there is no significant difference in other mid-life crises dimension between men and women sandwich generation people.

\section{Major findings of the study}

The result indicates that $12.2 \%$ of sandwich generation people have low level of mid-life crises. $11.83 \%$ of sandwich generation people have average level of mid-life crises and $75.95 \%$ of sandwich generation people have high level of mid-life crises. This shows that the sandwich generation people are more prone to mid-life crises.

The high level of mid-life crises was found in the dimension of family related issues and the low level of mid-life crises among sandwich generation people are found in self-related crises.

There is significant difference in mid-life crises between men and women sandwich generation people. The female sandwich generation people are at higher level than the male sandwich generation people in their mid-life crises.

There is significant difference in self-related and family-related dimensions of mid-life crises between men and women sandwich generation people. Female sandwich generation people are at higher level than the male sandwich generation people.

There found no significant difference in other mid-life crises dimension between men and women sandwich generation people. 


\section{DISCUSSION}

Midlife is a time to reassess what we want from life and align the goals with the values and set new goals to come out crises. Drug therapies are not recommended as treatment to overcome mid-life crises. It is highly recommended to seek psychological help, particularly when symptoms become severe [8].

Existential therapy is a good fit for mid-life crisesas it explores questions of how to live a meaningful life as well as focuses on your fundamental values and philosophical outlooks. The individual can do life audit: think about the times when they felt happiest, proudest and most fulfilled in career and personal life. Forming new productive goals helps to overcome midlife crises, it also helps the individual to be active and dynamic for enrichment of self and family. Individual can use rational thinking strategies to challenge any negative thoughts, situations and focus on what can be done to live meaningful life. Religious prayers, meditation and yoga are various attempts to rejuvenate and deal with life crises successfully [9].

There is always a critical need to cope with any crisis situation. This is because it has implications on various psychological as well as physical outcomes of individual life. By properly working through the grief process, the possibility of maladjustment in later life can be prevented [10].

\section{REFERENCES}

1. Best JW. Research in Education. New Delhi: Prentice Hall of India ; 1977.

2. Best JW, Khan JV. Research in Education. New Delhi: Prentice Hall of India; 1999.

3. Jarues E. Death and the mid-life crisis. Int J Psychoanal 1965;46:502-14.

4. Shek D. Midlife Crises in Chinese Men and Women. J Psychology 1996;130(1):109-19.

5. Gould R. Transformation. New York: Simon \& Schuster ; 1978.

6. Levinson DJ. The seasons of a man's life. New York: Knopf ; 1978.

7. Mangal SK. Statistics in Psychology and Education. New Delhi: Prentice Hall of India; 2005.

8. Khosla M. Need for coping with life crises: Implications for the Quality of life. J Indian Acad Appl Psychol 2008;34:46-52.

9. Sheehy G. Passages: predictable crises of adult life. New York: E.P. Dutton; 1976.

10. Sheehy G. Pathefinders. New York: Morrow ; 1981.

Acknowledgments - Nil

Funding - Nil.

Conflict of interest - Nil.

$* * * * * * * * * * * * * * * * * * * * * * * * * * * * * *$ 